Julian Perelman'

Joana Alves ${ }^{1}$

Ana Cláudia Miranda"

Céu Mateus

Kamal Mansinho"

Francisco Antunes

Joaquim Oliveiralv

José Poças ${ }^{\vee}$

Manuela Doroana'II

Rui Marques $^{\mathrm{VI}}$

Eugénio Teófilo ${ }^{\mathrm{vII}}$

João Pereira'

Escola Nacional de Saúde Pública. Universidade Nova de Lisboa. Lisboa, Portugal

" Hospital Egas Moniz. Centro Hospitalar de Lisboa Ocidental. Lisboa, Portugal

III Hospital de Santa Maria. Centro Hospitalar de Lisboa Norte. Lisboa, Portugal

Iv Hospitais da Universidade de Coimbra. Coimbra, Portugal

$\checkmark$ Centro Hospitalar de Setúbal. Setúbal, Portugal

vı Hospital de São João. Porto, Porto, Portugal

VII Hospital dos Capuchos. Centro Hospitalar de Lisboa Central. Lisboa, Portugal

Correspondence:

Julian Perelman

Escola Nacional de Saúde Pública

Universidade Nova de Lisboa

Avenida Padre Cruz

1600-560 Lisboa, Portugal

E-mail: jperelman@ensp.unl.pt

Received: 10/16/2012

Approved: 5/7/2013

Article available from: www.scielo.br/rsp

\section{Direct treatment costs of HIV/AIDS in Portugal}

\section{Custos diretos com tratamento do VIH/SIDA em Portugal}

\section{ABSTRACT \\ OBJECTIVE: To analyze the direct medical costs of HIV/AIDS in Portugal from the perspective of the National Health Service.}

METHODS: A retrospective analysis of medical records was conducted for 150 patients from five specialized centers in Portugal in 2008. Data on utilization of medical resources during 12 months and patients' characteristics were collected. A unit cost was applied to each care component using official sources and accounting data from National Health Service hospitals.

RESULTS: The average cost of treatment was $14,277 € /$ patient/year. The main cost-driver was antiretroviral treatment $(€ 9,598)$, followed by hospitalization costs $(€ 1,323)$. Treatment costs increased with the severity of disease from $€ 11,901$ ( $>500 \mathrm{CD} 4$ cells $/ \mu \mathrm{l})$ to $€ 23,351$ (CD4 count $\leq 50$ cells $\mu \mu \mathrm{l})$. Cost progression was mainly due to the increase in hospitalization costs, while antiretroviral treatment costs remained stable over disease stages.

CONCLUSIONS: The high burden related to antiretroviral treatment is counterbalanced by relatively low hospitalization costs, which, however, increase with severity of disease. The relatively modest progression of total costs highlights that alternative public health strategies that do not affect transmission of disease may only have a limited impact on expenditure, since treatment costs are largely dominated by constant antiretroviral treatment costs.

DESCRIPTORS: Acquired Immunodeficiency Syndrome, economics. AntiHIV Agents, economics. Health Care Costs. Economics, Medical. 


\section{RESUMO}

OBJETIVO: Analisar dos custos diretos médicos com VIH/SIDA, de acordo com a perspetiva do Serviço Nacional de Saúde, em Portugal.

MÉTODOS: Efetuou-se análise retrospectiva de registros médicos em amostra de 150 pacientes de cinco centros especializados em 2008. Foram obtidos dados de utilização de recursos médicos durante 12 meses e das características dos pacientes nesse período. Aplicou-se o custo unitário a cada componente de custo, usando fontes oficiais e dados contabilísticos dos hospitais.

RESULTADOS: O custo médio anual de tratamento foi de 14.277 euros por paciente. A parcela de custo mais importante foi o custo com o tratamento antirretroviral (9.598 euros), seguido dos custos de internação (1.323 euros). Os custos de tratamento com severidade aumentaram de 11.901 euros (> 500 CD4 células/ $\mu 1)$ para 23.351 euros $(\mathrm{CD} 4 \leq 50$ células/ $\mu 1)$. A progressão dos custos deve-se principalmente ao aumento dos custos de internação, dado que os custos com tratamento antirretroviral se mantêm constantes ao longo dos estádios.

CONCLUSÕES: O custo elevado do tratamento antirretroviral é compensado com o custo relativamente baixo da internação, apesar deste aumentar com a severidade. A baixa progressão dos custos totais revela que estratégias de saúde pública alternativas que não alterem a transmissão da doença terão apenas impacto limitado nas despesas, dado que os custos são largamente influenciados pelo do tratamento antirretroviral.

DESCRITORES: Síndrome de Imunodeficiência Adquirida, economia. Fármacos Anti-HIV, economia. Custos de Cuidados de Saúde. Economia Médica.

\section{INTRODUCTION}

HIV/AIDS represents a high financial burden for highand low-income countries, due to the high costs of antiretroviral therapy (ART), treatment of opportunistic infections, lost productivity and declines in human capital investment. ${ }^{2}$ However, many countries have little or poorly-validated evidence about costs of HIV/AIDS. ${ }^{5}$

Measuring the cost of treating HIV-infected persons is of particular importance. Ensuring universal and high-quality treatments at reasonable cost is a major objective of policy makers. Given the adverse economic climate, it is more essential than ever before that policy makers have access to credible economic evidence and reliable forecasts in making future resource allocation decisions. "Hot" questions concern the opportunity for expanded testing and early detection, pre-exposure prophylaxes, regular lab tests for CD4 cell count and viral load, choice of regimen options and treatment initiation thresholds in the HIV area. ${ }^{3,10,11,13}$ These complex issues require valid figures on treatment costs. As Schackman et a ${ }^{12}$ indicate, "if policy makers rely on outdated estimates of HIV care costs, treatment programs will be under-funded and the economic value of HIV prevention will be understated" (p.990).
Precise knowledge of treatment costs is indispensable in planning future health expenditures, producing budget impact analyses and defining financing policies. It is particularly relevant to identify the major cost drivers and the patients' characteristics that most influence treatment expenditures. Estimating how severity affects treatment costs can help predict future expenditures for different epidemiologic scenarios and screening policies; estimating the weight of hospitalization costs can help set adequate reimbursement schemes for hospitals and potential savings from shifting towards more out-patient care; international comparisons of ART costs can help identify differences in practices and pricing rules.

Levy et $\mathrm{al}^{5}$ observed in their review of the literature cost variations across studies, essentially related to different sources, estimation methods and populations. However, there is a positive relationship between costs and severity of disease (measured by the CD4 cell count). Chen et al ${ }^{1}$ find a cost variation from $\$ 13,885$ (CD4 count $\geq 350$ cells $/ \mu \mathrm{L})$ and $\$ 36,532(\mathrm{CD} 4$ count $<50$ cells $/ \mu \mathrm{L})$ for the United States (US) per year. Schackman et $\mathrm{al}^{12}$ measure substantial variation across severity groups (from $\$ 2,000$ to $\$ 4,700$ per month) also for the US. Sloan et $\mathrm{al}^{13}$ 
Table 1. Sample size and representativeness. Portugal, 2007.

\begin{tabular}{lccc}
\hline Hospital & Patients under treatment in 2007 (n) & $\%$ & Records (n) \\
\hline Hospital de Santa Maria (CH Lisboa Norte) & 2,490 & 12.7 & 35 \\
Hospital de São João & 1,590 & 8.1 & 34 \\
Hospital Egas Moniz (CH Lisboa Ocidental) & 1,650 & 8.2 & 28 \\
Hospitais Universidade Coimbra & 941 & 4.8 & 25 \\
Centro Hospitalar de Setúbal & 830 & 4.2 & 24 \\
Total & & & 146 \\
\hline
\end{tabular}

observe average yearly costs varying between $€ 15,970$ (CD4 counts of 351-500 cells $/ \mu \mathrm{L}$ ) and $€ 36,540$ (CD4 counts $<50$ cells $/ \mu \mathrm{L}$ ) for France. A study in Belgium shows variations between $€ 809$ and $€ 3,551$ per month. ${ }^{a}$

ART drugs are the major cost driver, although their weight decreases in the most severe cases. Sloan et al ${ }^{13}$ observe that ART drugs represent $76 \%$ of total costs, with a variation between $81 \%$ among the least severelyaffected patients (CD4 counts $>500$ cells $/ \mu \mathrm{L}$ ) and $41 \%$ among the most-affected ones. Chen et $\mathrm{al}^{1}$ show that ART represents $68 \%$ of total costs for patients above $350 \mathrm{CD} 4$ cells $/ \mu \mathrm{L}$, while it falls to $30 \%$ for the most severely affected patients $(<50 \mathrm{CD} 4$ cells $/ \mu \mathrm{L})$, for whom inpatient treatment and other drugs represent the major cost component (64\%). ART drugs represented $63 \%$ of total cost for Canada in 2005-2006, for $15 \%$ for inpatient care. ${ }^{4} \mathrm{~A}$ common pattern in these studies is that ART cost is relatively stable across CD4 strata, hence the major source of increase is due to other drugs and hospitalizations. Sloan et $\mathrm{al}^{13}$ and Krentz et al, ${ }^{4}$ who both consider longer periods, show that ART-related costs have been quite stable over time; hence, the small increases in yearly costs are essentially due to other components, with marked effects at later stages of disease. Recent contributions clarify the role of late presentation in substantially increasing immediate costs after treatment initiation. ${ }^{13}$

The perspective is that of the National Health Service (NHS), given that private facilities did not treat HIV cases at the time our study was performed. The 2011 Portuguese GDP per capita adjusted for inflation and purchasing power parity $(\$ 21,414)$ is lower than that of other high-income countries for which similar analyses have been performed, namely Belgium $(\$ 33,217)$, France $(\$ 29,938)$, Germany $(\$ 34,581)$, Italy $(\$ 27,053)$, Switzerland (\$ 39,600), and the US $(\$ 42,385) .^{\mathrm{b}}$ Despite lower wealth and healthcare expenditures per capita, coupled with NHS and hospitals' solvency problems, timely universal access to innovative drugs is guaranteed at unit costs that are comparable to those prevailing in richer European countries. In the present study we question (i) whether treatment costs differ in this context of scarcer resources, similar, e.g., to that prevailing in Eastern Europe countries; (ii) whether the potentially high burden of ART is compensated by hospitals through lower resource use in other care components; (iii) whether differences in cost composition affects the cost distribution across patients' groups. Portugal is the country in Western Europe with the highest rate of new cases and HIV-related mortality, so that high unit treatment costs likely transfer into high global expenditures. $^{\mathrm{c}}$

This study aimed to analyze the direct medical costs of HIV/AIDS in Portugal.

\section{METHODS}

A retrospective analysis of patient records was conducted in five HIV-AIDS specialized treatment centers in Portugal from January 1, 2008 to December 31, 2008. This period (12 months) was chosen to cover the relevant costs associated with medical practices and follow-up management at different stages of the disease.

Specialized centers were chosen representing $38.1 \%$ of the total patients following consultations in Portugal (Table 1). Given that the data collection was based on medical records, our sample was limited to 150 records. The number of records collected per hospital was proportional to their representativeness with respect to the total number of patients.

The following inclusion criteria were adopted: known HIV infection before January 1, 2008, being at least 18 years old and not suffering from severe psychological disease or severe mental disability, having received regular care in the center (at least two episodes of inpatient or outpatient resource use per year) during the study period, not being transferred to or from another hospital during the year, and having provided informed

a Caekelbergh K, Moeremans K, Annemans L, et al. Cost of care for HIV/AIDS in Belgium according to disease stage. Poster session presented at the $11^{\text {th }}$ European AIDS Conference/EACS; 2007 Oct 24-27; Madrid, Spain.

${ }^{\mathrm{b}}$ Organization for Economic Co-Operation and Development. OECD.StatExtracts: Gross domestic product - GDP [cited 2013 Apr 7]. Available from: http://stats.oecd.org/Index.aspx?DatasetCode=SNA_TABLE1

cEuropean Centre for Disease Prevention and Control; WHO Regional Office for Europe. HIV/AIDS surveillance in Europe 2009. Stockholm; 2010. 


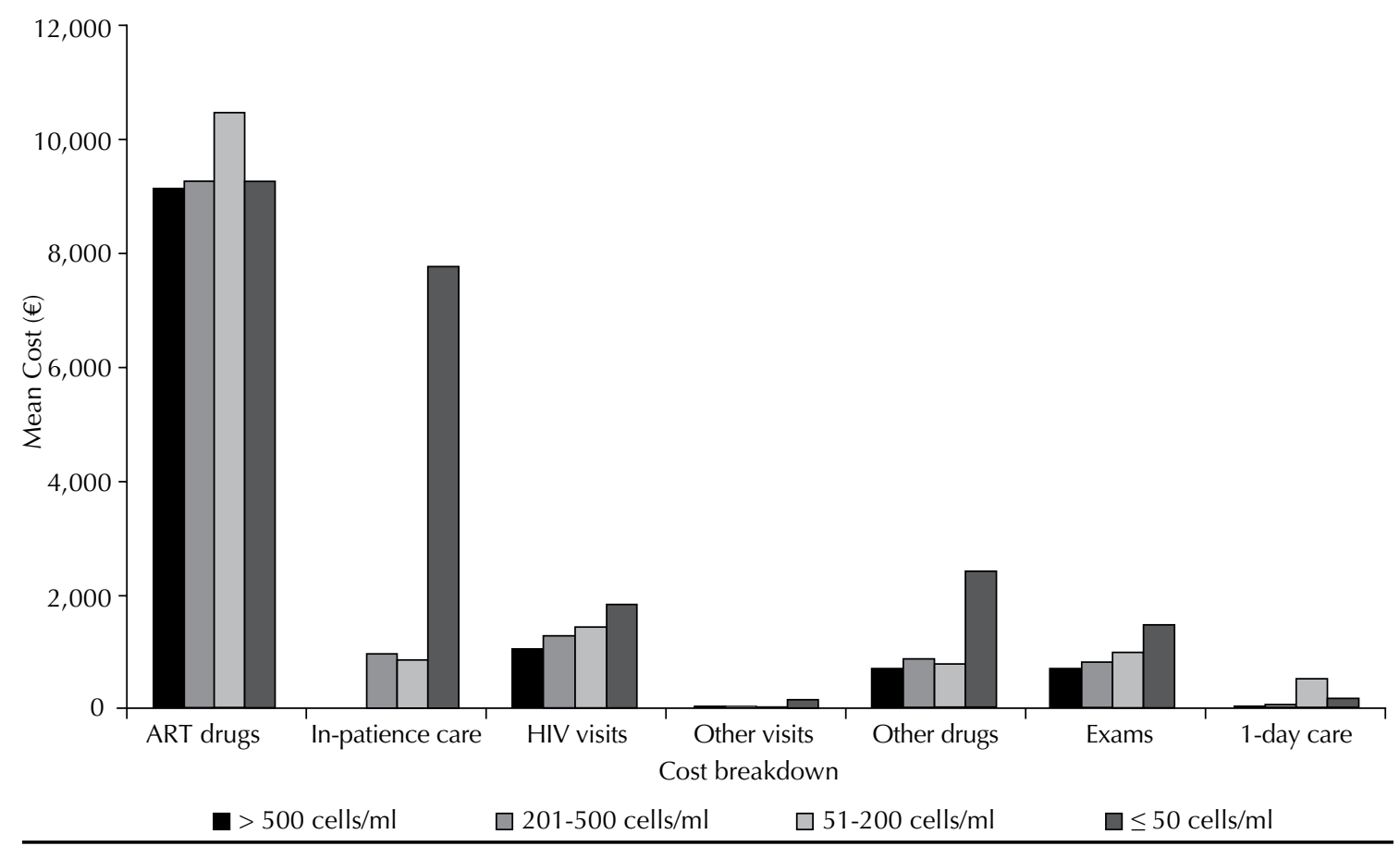

Figure. Components of average costs per patient year, per stage of disease. Portugal, 2008.

consent. A list of eligible patients meeting the inclusion criteria of the study was produced by the center. We ranked the patients into four groups based on the CD4 cell count and selected an equal number of patients from each group at random. We marked the selected patients on the screening list and sent the list back to the investigator. The investigator requested informed consent from the patients and collected the data on that patient.

Inpatient resource use data was collected on a "per hospitalization" level. Outpatient resource use data was collected on a "per consultation" level. The resource use was collected for each inpatient episode or outpatient consultation and allocated to the day of its occurrence. The data were by the medical staff from the participating center, with confidentiality guaranteed.

Items collected from the patient files included (i) patient's demographic and clinical characteristics; (ii) outpatient resource use (HIV-related specialists and other physicians' consultations, nurse, physiotherapist and social assistant consultations, emergency visits, lab tests, ART drugs, prophylactic drugs for opportunistic infections and other non-antiretroviral (ARV) drugs); (iii) inpatient resource use (hospital stays related to HIV/ AIDS or to opportunistic infections, with associated All-Patient Diagnosis Related Groups (AP-DRG).
As regards ART drugs, we assumed that drugs were taken until the next consultation. If the next consultation occurred after more than 120 days, considered the maximum time between consultation following Portuguese Guidelines for HIV Treatment, we considered the therapy was followed for 120 days. ${ }^{\mathrm{d}}$ As for non-ART drugs, when no information was available, length of treatment was given by the summary of product characteristics approved by the Therapeutic Compendium. ${ }^{\text {e }}$ For patients at stages 4, 5 and 6 , some drugs were taken as prophylaxy. The assumed length of treatment for each medication, as prophylactic or normal treatment, was discussed with medical researchers. Complete data on resource use for each item can be provided on demand. Due to invalid responses on resource use, four questionnaires were excluded from the sample.

Total costs were computed by multiplying each resource item by its unit value. Unit costs for consultations were obtained from the 2006 analytical accounting of the Administração Central do Sistema de Saúde - ACSS ${ }^{\mathrm{f}}$ (National System of Health, Central Adminsitration). The drugs were evaluated using the ACSS catalog of public health supply, which lists information on unitary costs of goods and services acquired in the public health sector procurement contracts. ${ }^{\mathrm{g}}$ Since most drugs used in the study were provided at the hospital, this catalog represented the

${ }^{d}$ Coordenação Nacional para a Infecção de VIH/Sida. Recomendações portuguesas para o tratamento da infecção VIH-Sida. Lisboa; 2009. e Infarmed. InfoMed: base de dados de medicamentos. Governo de Portugal, Ministério da Saúde, Autoridade Nacional do Medicamento e Produtos de Saúde [cited 2011 Mar 31]. Available from: http://www.infarmed.pt/infomed/inicio.php

${ }^{\dagger}$ Administração Central do Sistema de Saúde. Contabilidade analítica 2006: hospitais do SNS. Lisboa; 2007.

g Administração Central do Sistema de Saúde. Catálogo de aprovisionamento público da saúde. Lisboa, Portugal [cited 2011 Mar 31 ]. Available

from: http://www.catalogo.min-saude.pt/caps/publico/default.asp 
Table 2. Characteristics of the sample, Portugal, 2008.

\begin{tabular}{|c|c|c|}
\hline Characteristic & Frequency & $\%$ \\
\hline \multicolumn{3}{|l|}{ Sex } \\
\hline Female & 32 & 21.9 \\
\hline Male & 113 & 77.4 \\
\hline Missing & 1 & 0.7 \\
\hline \multicolumn{3}{|l|}{ Age category } \\
\hline$\leq 30$ & 15 & 10.3 \\
\hline 31 to 40 & 58 & 39.7 \\
\hline 41 to 50 & 41 & 28.1 \\
\hline 51 to 60 & 18 & 12.3 \\
\hline 61 to 70 & 10 & 6.8 \\
\hline$\geq 71$ & 2 & 1.4 \\
\hline Missing & 2 & 1.4 \\
\hline \multicolumn{3}{|l|}{ Transmission category } \\
\hline Heterosexual & 75 & 51.4 \\
\hline Homosexual/bisexual & 20 & 13.7 \\
\hline Intravenous drug use & 48 & 32.9 \\
\hline Blood transfusion & 1 & 0.7 \\
\hline Missing & 2 & 1.4 \\
\hline \multicolumn{3}{|l|}{ CD4 count (individual-month) } \\
\hline Stage 1: CD4 $\geq 500$ & 342 & 25.3 \\
\hline Stage $2: 500 \leq \mathrm{CD} 4<200$ & 545 & 40.3 \\
\hline Stage 3: $200 \leq \mathrm{CD} 4<50$ & 371 & 27.5 \\
\hline Stage 4: $50 \leq \mathrm{CD} 4$ & 93 & 6.9 \\
\hline $\begin{array}{l}\text { CD4 count at detection (mean } \\
\text { value) }\end{array}$ & 292.33 & \\
\hline \multicolumn{3}{|l|}{ ART medication ${ }^{\mathbf{a}}$} \\
\hline $\begin{array}{l}\text { NRTI (TDF/FTC, AZT/3TC, } \\
\text { TDF) }\end{array}$ & 133 & 91.1 \\
\hline NNRTI (EFV, NVP) & 53 & 36.3 \\
\hline PI (LPV, RTV, ATV) & 83 & 56.8 \\
\hline $\mathrm{FI}(\mathrm{T}-20)$ & 1 & 0.7 \\
\hline II (Raltegravir) & 5 & 3.4 \\
\hline \multicolumn{3}{|l|}{ Detection setting } \\
\hline Hospital & 79 & 54.1 \\
\hline Primary Care Center & 30 & 20.6 \\
\hline CAT/CAD & 20 & 13.7 \\
\hline Other & 10 & 6.8 \\
\hline Missing & 7 & 4.8 \\
\hline \multicolumn{3}{|l|}{$\begin{array}{l}\text { Number of comorbidities in } \\
\text { previous years }\end{array}$} \\
\hline 0 & 92 & 63.0 \\
\hline 1 & 35 & 24.0 \\
\hline$>1$ & 19 & 13.0 \\
\hline
\end{tabular}

3TC: lamivudine; ATV: atazanavir; AZT: zidovudine; CAT: Centro para Atendimento de Toxicodependentes (Center for Intravenous Drug Users); CAD: Centro de Atendimento e Detecção Precoce (Center for HIV Testing and Counselling); EFV: efavirenz; FTC: emtricitabine; LPV: lopinavir; NNRTI: non-nucleoside reverse-transcriptase inhibitor; NRTI: nucleoside reverse-transcriptase inhibitor; NVP: nevirapine; PI: protease inhibitor; RTV: ritonavir; TDF: tenofovir.

a The most common drugs reported in order of frequency most adequate information source. As regards other drugs not provided at hospitals, we used the reference price available in the Therapeutic Compendium, which lists pharmacy retail prices. Inpatient stays (AP-DRGs), exams, laboratory tests and complementary means of diagnostic were valued by official sources (Decree 839-A/2009 of 31 July 2009). Complete data on the valuation of each item can be provided on demand.

In addition to computing average yearly costs per cost component and stage of disease, a multivariate analysis was performed to estimate the cost determinants. Cost data in our sample were right-skewed (skewness $=1.64$ ) and heavy tailed (kurtosis $=5.94$ ), which is the common pattern of cost distributions in the literature. ${ }^{8}$ Normality is rejected using the Shapiro-Wilk test $\left(x^{2}=40.41 ; \mathrm{p}<0.05\right)$. Non-negativity also renders the use of ordinary least square (OLS) inadequate.

We used Generalized Linear Models (GLM) and adopt the Manning \& Mullahy ${ }^{7}$ algorithm for choosing adequate distribution. The Ordinary Least Squares model was not rejected because the heavy-tailed log-scale residuals (kurtosis $>3$ ). That model has logged costs and also performs better in terms of goodnessof-fit. The following covariates were included: stage of disease, age, sex, transmission category, detection setting, hospital and number of comorbidities.

This study was approved by the Comissão Nacional de Protecção de Dados (Portugal), Process no. 741/2010, authorization 923/2010. It was also approved by the Ethical Commissions of the five specialized centers involved in the data collection.

\section{RESULTS}

The sample were composed by 146 patients $(77.0 \%$ men), $50.0 \%$ of whom were $<40$ years (Table 2 ). The main transmission category was heterosexual contact, followed by intravenous drug use. The detection settings were mainly hospitals and primary care centers. The average CD4 count at the detection in the sample was 292.3 cells $/ \mu 1$. The patients' distribution across severity groups (based on CD4 count) during the year was almost equal across groups due to our sampling method. A large variety of ART regimens was found (29), among which the most common were: two nucleoside reversetranscriptase inhibitors + one protease inhibitor, and two nucleoside reverse-transcriptase inhibitors + one non-nucleoside reverse-transcriptase inhibitors.

Taking all patients together, major costs were related to ART treatments ( $€ 9,598 /$ patient/year, $67.0 \%$ of total cost), followed by HIV consultations ( $€ 1,323,9.0 \%$ of total cost $)$, and hospitalization costs ( $€ 1,400,10.0 \%$ of total cost), giving a cost of $€ 14,277 /$ patient/year (Table 3). Other components included other drugs (7.0\%), exams $(6.0 \%)$ and one-day care $(2.0 \%)$. 
Table 3. Average costs $(€)$ per patient year and its components, a per stage of disease. Portugal, 2008.

\begin{tabular}{|c|c|c|c|c|c|c|c|c|c|}
\hline CD4 cells count & Total & ART drugs & $\begin{array}{l}\text { Inpatient } \\
\text { care }\end{array}$ & HIV visits & $\begin{array}{l}\text { Other } \\
\text { visits }\end{array}$ & $\begin{array}{l}\text { Other } \\
\text { drugs }\end{array}$ & Exams & $\begin{array}{c}\text { One-day } \\
\text { care }\end{array}$ & $\begin{array}{c}\text { Care without } \\
\text { ART }\end{array}$ \\
\hline$>500$ & 11,901 & $9,199(77)$ & $0(0)$ & $1,061(9)$ & $79(1)$ & $770(6)$ & $723(6)$ & $69(1)$ & 2,273 \\
\hline 201 to 500 & 13,538 & $9,282(69)$ & $1,011(7)$ & $1,337(10)$ & $72(1)$ & $897(7)$ & $848(6)$ & $90(1)$ & 3,435 \\
\hline 51 to 200 & 15,279 & $10,514(69)$ & $923(6)$ & $1,401(9)$ & $68(0)$ & $810(5)$ & $1,020(7)$ & $543(4)$ & 3,428 \\
\hline$\leq 50$ & 23,351 & $9,268(40)$ & $7,815(33)$ & $1,888(8)$ & $182(1)$ & $2,480(11)$ & $1,515(6)$ & $202(1)$ & 4,216 \\
\hline All & 14,277 & $9,598(67)$ & $1,199(8)$ & $1,323(9)$ & $80(1)$ & $950(7)$ & $910(6)$ & $217(2)$ & 3,193 \\
\hline Mean resource use $\mathrm{e}^{\mathrm{b}}$ & - & - & 0.25 & 4.55 & 1.78 & - & - & 0.51 & - \\
\hline
\end{tabular}

ART: antiretroviral therapy

${ }^{a}$ Values between brackets indicate the percentage of total costs.

${ }^{\mathrm{b}}$ Mean value for each item (i.e., average number of inpatientstays, HIV consultations, other consultations and one-day care episodes). Non-available values are those that refer to very heterogenous services that it would not make sense to aggregate into a single value.

As regards yearly average costs per stage of disease, patients with more than $500 \mathrm{CD} 4$ cells/ $\mu 1$ experienced an $€ 11,901$ average cost, which increased as the CD4 count decreased (Table 3, Figure). The highest costs were observed for the most severely-affected patients (CD4 count $<50$ cells $/ \mu 1$ ), reaching $€ 23,351 /$ patient/year. While the costs with hospitalization were non-existent in the first stage, they increased in the final stage to an average $€ 7,815 /$ patient/year ( $33.0 \%$ of total costs). ART drugs represented the major cost driver at all stages, although to a lesser extent in the last stage of disease ( $40.0 \%$ of total costs) compared to other stages (always more than $60.0 \%$ of total cost). ART costs were stable across CD4 strata. Specialist consultations, exams, one-day care and other drugs represented $10.0 \%$ or less of total costs. Cost increases were small between stage 2 and stage 3 except for one-day care. Major increases occurred in the final stage.

Multivariate analysis indicated that average costs were not significantly related to any parameter except stage of disease, with a significantly higher cost at the final stage (Table 4). Adjusting for other factors, we do not observed any significant cost differences between stages of disease except for the most severely-affected patients. Cost progression across stages could not be considered as significant, except for stage 2 where costs were higher than for stage 3 .

\section{DISCUSSION}

The average treatment cost was $€ 14,277 /$ year, mostly due to ART drugs (67.0\%), followed by HIV consultations $(9.0 \%)$, inpatient care $(8.0 \%)$ and other drugs $(7.0 \%)$. Although the weight of hospitalization costs was substantially higher for the most severely-affected patients (33.0\%), ART was always the major cost driver $(40.0 \%)$, which was stable across severity groups. Costs significantly increased to $€ 23,351$ for patient with a CD 4 count below 50 cells $/ \mu$. No significant differences were observed across patient groups, namely age, sex, presence of previous comorbidities and place of detection. The only statistically significant difference is related to the stage of disease.

Average yearly treatment costs $(€ 15,293$ at 2012 prices $)^{\mathrm{h}}$ for Portugal are lower than those obtained for France $^{13}$ ( $€ 21,592$ at 2012 prices) and Germany ${ }^{9}$ ( $€ 25,526$ at 2012 prices). They are also lower than those obtained for Switzerland ( $€ 22,458$ at 2012 prices), but are similar to those in the US ( $€ 18,565$ at 2012 prices), and Italy ( $€ 15,426$ at 2012 prices). ${ }^{1,6,14}$ However, the last three studies rely on older data and thus refer to older and cheaper treatments.

Despite the difficulty in comparing studies with different methodologies and populations, a rough comparison with French data can provide some useful insights, given that both studies use recent information. ${ }^{5,13}$ The major discrepancy is driven by the last stage of disease (average cost of $€ 25,013$ for Portugal, $€$ 38,014 for France, in 2012 prices), essentially due to differences in hospitalization costs ( $€ 8,371$ versus $€ 15,586$, in 2012 prices). This discrepancy is certainly due in part to differences in severity between patients in the final stage of disease; our sample does not include any patient who died during the study period, while this was the case for more than 2,000 individuals-month in Sloan et al. ${ }^{13}$ These cases represent by far the highest expenditures. The low average number of inpatient stays in our study ( 0.25 per year); as a comparison point, Caekelbergh

h All values from our study and references have been converted to 2012 Euros to allow for comparison. We used inflation rates from: Organization for Economic Co-Operation and Development. OECD.StatExtracts: monthly comparative price levels [cited 2013 Apr 5]. Available from: http:// stats.oecd.org/Index.aspx?DataSetCode=CPL\# and conversion rates from: XE Currency Converter [website]. [cited 2013 Apr 5]. Available from: http://www.xe.com/currencyconverter/ 
Table 4. Regression results for mean cost. Portugal, 2008.

\begin{tabular}{|c|c|c|}
\hline Variable & Estimate & Standard error \\
\hline Intercept & $9.752^{\mathrm{a}}$ & 0.27 \\
\hline \multicolumn{3}{|l|}{ Age categories } \\
\hline age1 & -0.164 & 0.18 \\
\hline age2 & 0.059 & 0.12 \\
\hline age3 & -0.061 & 0.13 \\
\hline$>1$ comorbidity & -0.086 & 0.13 \\
\hline Male & -0.007 & 0.11 \\
\hline \multicolumn{3}{|l|}{ Detection setting } \\
\hline Hospital & 0.038 & 0.18 \\
\hline Primary care center & 0.041 & 0.20 \\
\hline CAT/CAD & 0.038 & 0.22 \\
\hline \multicolumn{3}{|l|}{ Other } \\
\hline Stage of disease (CD4 count) & \multicolumn{2}{|c|}{ Reference category } \\
\hline$>500$ & $-0.281^{\mathrm{a}}$ & 0.12 \\
\hline 201 to 500 & 0.025 & 0.11 \\
\hline 51 to 200 & 0.038 & 0.11 \\
\hline$\leq 50$ & $0.390^{\mathrm{a}}$ & 0.14 \\
\hline Hospital & \multicolumn{2}{|c|}{ Not reported } \\
\hline $\mathrm{N}$ & \multicolumn{2}{|c|}{132} \\
\hline Akaike Information Criterion & \multicolumn{2}{|c|}{221.08} \\
\hline Bayesian Information Criterion & \multicolumn{2}{|c|}{270.60} \\
\hline \multicolumn{3}{|c|}{$\begin{array}{l}\text { CAT: Centro para Atendimento de Toxicodependentes (Center } \\
\text { for Intravenous Drug Users); } \\
\text { CAD: Centro de Atendimento e Detecção Precoce (Center for } \\
\text { HIV Testing and Counselling) } \\
\text { a Significance for two tailed tests are shown as } \mathrm{p}<0.05 \text {. } \\
\text { The smaller sample is due to observations with missing } \\
\text { values being withdrawn. }\end{array}$} \\
\hline
\end{tabular}

et $\mathrm{al}^{\mathrm{a}}$ find average values that are higher for all CD4 count groups except 351-500 cells/ $\mu 1$ (other papers do not provide information on resource use).

Other discrepancies are worth noticing. HIV consultations in France are mostly performed through one-day care, the unit costs of which are higher than usual visits; this is a relevant difference with Portugal (HIV consultations represent on average $€ 1,453$, for $€ 2,417$ for one-day care in France, at 2012 prices). ART drugs also represent a substantially higher burden in France $(€ 14,909$ versus $€ 10,281$, at 2012 prices, or $74 \%$ versus $67 \%$ in Portugal). A potential explanation, considering the similarity of unit costs, could be that Sloan et a $\mathrm{l}^{13}$ estimate ART costs through modelling, using six ART regimens. Our data reflect a variety of regimens (29) in real practice and account for potential compliance problems.

The major limitation of the study is the sample size. Due to the absence of electronic records, we limited our study to a sample of $150 \mathrm{HIV}$-infected people who were followed retrospectively during one year. The advantage of this procedure was the ability to collect large and exhaustive information for each patient, which render our data highly reliable. The limited sample explains the lack of significant variations across patients' characteristics, despite the use of sophisticate econometric methods. A larger sample would have increased the probability of including more severe cases, e.g., patients who died during the study period, avoiding a potential source of under-estimation. Considering a longer period could help assess the impact of rapid changes in treatment patterns.

Direct treatment costs for HIV in Portugal are comparable to, or slightly lower than, those observed in other high-income countries. As expected, ART is the main cost driver, which is relatively stable across severity groups. The high burden related to ART at all stages of disease is counterbalanced by the substantially lower inpatient costs compared with other countries. Inpatient costs, however, increase dramatically with severity of disease, arguing in favor of keeping patients at low-severity stages of disease for as long as possible. The relatively modest progression of total costs highlights that alternative public health strategies that do not affect transmission of disease may only have a limited impact on expenditures, since treatment costs are largely dominated by ART costs that are constant across stages of disease. 


\section{REFERENCES}

1. Chen RY, Accortt NA, Westfall AO, Mugavero MJ, Raper JL, Cloud GA, et al. Distribution of health care expenditures for HIV-infected patients. Clin Infect Dis. 2006;42(7):1003-10. DOI:10.1086/500453

2. Hutchinson $A B$, Farnham PG, Dean HD, Ekwueme $\mathrm{DU}$, Rio $\mathrm{C}$ del, Kamimoto $\mathrm{L}$, et al. The economic burden of HIV in the United States in the era of highly active antiretroviral therapy: evidence of continuing racial and ethnic differences. I Acquir Immune Defic Syndr. 2006;43(4):451-7. DOI:10.1097/01.qai.0000243090.32866.4e

3. Kahn JG, Marseille E, Moore D, Bunnell R, Were W, Degerman R, et al. CD4 cell count and viral load monitoring in patients undergoing antiretroviral therapy in Uganda: cost effectiveness study. BMJ. 2011;343:d6884. DOI:10.1136/bmj.d6884

4. Krentz HB, Gill MJ. Cost of medical care for HIVinfected patients within a regional population from 1997 to 2006. HIV Med. 2008;9(9):721-30. DOI:10.1111/j.1468-1293.2008.00613.x

5. Levy AR, James D, Johnston KM, Hogg RS, Harrigaan BP, Soboley B, et al. The direct costs of HIV/ AIDS care. Lancet Infect Dis. 2006;6(3):171-7. DOI:10.1016/S1473-3099(06)70413-3

6. Lowy A, Page J, Jaccard R, Ledergerber B, Somaini B, Weber R, et al. Costs of treatment of Swiss patients with HIV on antiretroviral therapy in hospital-based and general practice-based care: a prospective cohort study. AIDS Care. 2005; 17(6):698-710. DOI:10.1080/09540120412331336689

7. Manning WG, Mullahy J. Estimating log models: to transform or not to transform? J Health Econ. 2001;20(4):461-94. DOI:10.1016/S0167-6296(01)00086-8

8. Manning WG. Dealing with skewed data on costs and expenditures. In: Jones AM, editor. The Elgar companion to health economics. Cheltenham: Edward Elgar Publishing; 2006. p.439-46.

9. Mostardt S, Hanhoff N, Wasem J, Goetzenich A, Schewe K, Wolf E, et al. Cost of HIV and determinants of health care costs in HIV-positive patients in Germany: results of the DAGNÄ K3A Study. Eur J Health Econ. 2013;14(5):799-808. DOI:10.1007/s10198-012-0425-4

10. Paltiel AD, Weinstein MC, Kimmel AD, Seage GR $3^{\text {rd }}$, Losina $\mathrm{E}$, Zhang $\mathrm{H}$, et al. Expanded screening for HIV in the United States: an analysis of costeffectiveness. N Engl J Med. 2005;352(6):586-95. DOI:10.1056/NEJMsa042088

11. Paltiel AD, Freedberg KA, Scott CA, Schackman BR, Losina E, Wang B, et al. HIV preexposure prophylaxis in the United States: impact on lifetime infection risk, clinical outcomes, and cost-effectiveness. Clin Infect Dis. 2009;48(6):806-15. DOI:10.1086/597095

12. Schackman BR, Gebo KA, Walensky RP, Losina E, Muccio T, Sax PE, et al. The lifetime cost of current human immunodeficiency virus care in the United States. Med Care. 2006;44(11):990-7. DOI:10.1097/01.mlr.0000228021.89490.2a

13. Sloan CE, Champenois K, Choisy $P$, Losina $E$, Walensky RP, Schackman BR, et al. Newer drugs and earlier treatment: impact on lifetime cost of care for HIV-infected adults. AIDS. 2012;26(1):45-56. DOI:10.1097/QAD.0b013e32834dce6e

14. Tramarin A, Campostrini S, Postma MJ, Calleri G, Tolley K, Parise N, et al. A multicentre study of patient survival, disability, quality of life and cost of care: among patients with AIDS in northern Italy. Pharmacoeconomics. 2004;22(1):43-53. DOI:10.2165/00019053-200422010-00004

This study was supported by the Coordenação Nacional para a Infeção VIH/SIDA, Alto Comissariado para Saúde (Grant CE-HIV/AIDS). The authors declare that there are no conflict of interests. 